\title{
ABDUKCIA A JEJ MIESTO VO VEDE A FILOZOFII ${ }^{1}$
}

LUKÁŠ BIELIK, Univerzita Komenského v Bratislave, Filozofická fakulta, Katedra logiky a metodológie vied, Bratislava, SR

BIELIK, L.: Abduction and its Place in Science and Philosophy FILOZOFIA, 76, 2021, No 6, pp. $391-406$

\begin{abstract}
The paper analyzes four different aspects of abduction when used in science and philosophy. As a preliminary step, it presents the main kinds of abductive arguments in terms of their logical form and extralogical criteria of evaluation. Subsequently, it discusses the standard functions of abductive inference. Finally, it pays attention to four levels of difference in comparing the use of abduction in science with that in philosophy. In particular, it is argued that the difference between abduction in science and philosophy involves the distinct kinds of hypotheses, a different notion of explanation, a difference in the contexts of abductive reasoning, and different criteria for the hypothesis-selection.
\end{abstract}

Keywords: Abduction in philosophy - Abduction in science-Contexts - Differences - Explanation - Hypotheses

\section{1. Úvod}

Veda využíva deduktívne i induktívne myšlienkové postupy pri budovaní teórií i modelov a pri ich systematickom rozvíjaní. Zapája ich tiež do procesov testovania i hodnotenia hypotéz a využíva ich aj pri vysvetlení, rekonštrukcii minulých udalostí či prognózovaní tých budúcich. Dedukcia i indukcia majú svoje miesto aj pri konštrukcii a testovaní filozofických téz či teórií (aspoň v prípade niektorých filozofických smerov a prístupov), hoci charakter filozofických testov sa od tých vedeckých do určitej miery líši. ${ }^{2}$ Pre čast' filozofických smerov a prístupov je typické práve používanie deduktívnych argumentov na zdôvodnenie určitej tézy či jej kritiku prostredníctvom odvodenia dôsledkov, ktoré sú v rozpore s prijatými predpokladmi. Deduktívne a induktívne usudzovanie a deduktívne a induktívne úsudky (ako výsledky rovnomenných

\footnotetext{
${ }^{1}$ D̆akujem Zdeňke Jastrzembskej a Marekovi Pichovi za cenné pripomienky k rovnomennej prezentácii vychádzajúcej z prvotnej verzie článku, ktorú som predniesol na Jednotě filosofické v Brne. Ďakujem aj obom anonymným recenzentom časopisu za konštruktívne pripomienky a spätnú väzbu k pôvodnej verzii state.

${ }^{2} \mathrm{~K}$ využívaniu deduktívnych a induktívnych postupov vo fillozofii pozri napríklad Cornman a kol. (1992, 1. kapitola).
} 
myšlienkových postupov) tak patria do štandardného repertoára konceptuálnych a teoretických metód, ktoré sa využívajú vo vede i filozofii. Okrem nich však vedci i filozofi využivajú aj osobitný typ myšlienkového postupu, ktorý je známy pod termínmi abdukcia, retrodukcia, hypotéza či odvodenie najlepšieho vysvetlenia (angl. inference to the best explanation) (pozri Niiniluoto 1999; 2018, 1; Psillos 2011). A hoci abdukcia má svoje miesto ako pri generovaní a formulovaní nových hypotéz, tak aj pri ich testovaní a hodnotení, predsa sa môže zdat', že všeobecné povedomie o jej funkciách a používaní je medzi vedcami i filozofmi slabšie ako v prípade dedukcie či indukcie. ${ }^{3}$

Ked’že vo vede i filozofii nachádzame viaceré abduktívne argumenty, môžeme prijat' tézu, že abdukcia sa ako myšlienkový postup využíva v oboch oblastiach poznávania. Otázkou však ostáva, do akej miery je používanie abdukcie vo vede odlišné od jej používania vo filozofii? Aké znaky sú pre abdukciu konštantné a ktoré sa menia v závislosti od oblasti jej použitia?

V tejto štúdii argumentujem v prospech tézy, že existujú viaceré (substantívne) rozdiely medzi povahou abdukcie vo vede a jej povahou vo filozofii. Na jej podporu uvádzam viaceré dôvody, ktoré súvisia so všeobecne akceptovanými metodologickými rozdielmi vedy a filozofie. Zvolím si nasledujúci postup: Najskôr v druhej časti priblížim abdukciu ako osobitý druh argumentu, pričom uvediem jej pôvodnú formu (Ch. S. Peirce) i modernú podobu. Dôležité rozlíšenia možných kontextov použitia abdukcie zavediem v tretej časti. Napokon hlavnú tézu, ako aj dôvody na jej prijatie, približim vo štvrtej časti. Ukážem, že odlišnosti medzi abdukciou vo vede a filozofii možno pozorovat' na štyroch základných úrovniach: na logicko-sémantickej úrovni hypotézy a evidenčného výroku, na úrovni pojmu vysvetlenia, na úrovni kontextu použitia a na úrovni selekčných kritérií. Záverečná čast' štúdie rekapituluje hlavné výsledky.

\section{Abdukcia ako inferencia sui generis}

Začnime jednoduchým príkladom: Začiatkom roka 2021 som očakával zásielku z Anglicka, no nedorazila v dohodnutom termíne. Ak by sa cestou „stratila“, vysvetl'ovalo by to, prečo včas nedorazila. Internetová stránka predajcu, z ktorej som si tovar objednal, však v čase objednávky uvádzala upozornenie, že zásielky do európskych krajín (vrátane Slovenska) môžu meškat' oproti štandardným termínom v súvislosti s Brexitom i pandemickou situáciou. Ak by teda moja zásielka meškala pre opatrenia súvisiace $\mathrm{s}$ Brexitom i pandemickou situáciou, tiež by to vysvetl'ovalo, prečo som

\footnotetext{
${ }^{3}$ Nájdu sa, samozrejme, vedci, ktorí doceňujú význam abdukcie. V oblasti psychológie abdukciu ako užitočný inferenčný nástroj približuje a propaguje Haig $(2008 ; 2014)$. Spomedzi filozofov využitel'nost' abdukcie obhajujú napríklad Psillos (1999, 4. kapitola) či Williamson (2016; 2018, 6. kapitola).
} 
zásielku nedostal $\mathrm{v}$ štandardnom termíne. Toto vysvetlenie som tak v danej chvíli považoval za lepšie vysvetlenie faktu, že zásielku som včas nedostal, ako vysvetlenie, ktoré predpokladalo, že zásielka sa cestou stratila. Preto som sa aj priklonil k hypotéze, že moja zásielka meškala pre Brexit a aktuálny stav pandémie, a nie z dôvodu straty (napokon mi ju doručili).

Úvaha, ktorá je v pozadí tohto príkladu, zodpovedá abduktívnemu usudzovaniu, pričom jeho výsledok (úsudok) možno rekonštruovat' ako príklad abduktívneho argumentu. Vo všeobecnosti totiž abduktívne usudzovanie vychádza zo situácie, ked' máme pred sebou určité empirické dáta (ich opis) alebo empirický stav vecí, ktoré si vyžadujú vysvetlenie (odpoved' na otázku, prečo daný stav vecí nastal). Následne hl'adáme hypotézu, ktorá by tento stav vecí vysvetlila. Ak sú $\mathrm{k}$ dispozícii viaceré alternatívne hypotézy, vyberieme spomedzi nich tú, ktorá predstavuje (vzhl'adom na kontext a určité kritériá) najlepšie vysvetlenie. Schopnost' hypotézy vysvetlit' predmetný stav vecí sa považuje za dôvod na jej (dočasné) prijatie.

Uvedený myšlienkový postup i jeho výsledná podoba vo forme abduktívneho argumentu môžu mat' viaceré podoby, ktoré sa líšia nielen svojou logickou formou, ale aj metodologickými kritériami a ciel'mi, ktoré spoluurčujú ich spol’ahlivost' a funkciu. Niektoré z nich si približžme v tejto i d’alšej časti.

Charles S. Peirce sa štandardne považuje za „otca“ abdukcie ako inferencie sui generis. Peirce síce formuloval svoju koncepciu abdukcie pôvodne v rámci tradičnej sylogistiky, no neskôr ju zasadil do svojej dvojdimenzionálnej koncepcie usudzovania, kde úsudky (argumenty) boli hodnotené z hladiska dvoch kritérií: a) produktívnosti (angl. uberty) a b) istoty (angl. security). Dedukcia (ako myšlienkový postup i argument) podl'a Peirca maximalizuje istotu a minimalizuje produktívnost'. Abdukcia, naopak, maximalizuje produktívnost' a minimalizuje istotu. Indukcia (chápaná najmä ako enumeratívna indukcia) je napokon niekde na pomedzí oboch kritérí (pozri CP $8.383 ;{ }^{4}$ a tiež Psillos 2011, 121).

Peirce vo svojom neskoršom období stotožnil abdukciu s postupom, ktorému zodpovedá argument s nasledujúcou formou (CP 5.189):

\section{(PA)}

Pozorovali sme fakt E, ktorý je prekvapivý.

Ak by $\mathrm{H}$ bola pravda, E by bolo zrejmé.

Je dôvod mysliet’ si, že H je pravda.

\footnotetext{
4 Štandardná referencia CP odkazuje na súborné dielo Collected Papers of Charles Sanders Peirce (pozri Peirce 1931 - 1958).
} 
Ako príklad argumentu, ktorý zodpovedá schéme (PA), možno uviest’ nasledujúci úsudok:

\section{(PA.1)}

Pozorujem, že zámka na chatke je vylomená.

Ak by sa do chatky vlámal zlodej, vysvetl'ovalo by to, prečo je zámka vylomená.

Je dôvod mysliet' si, že chatku vykradol zlodej.

Moderné podoby abdukcie sú do vel'kej miery modifikáciou schémy (PA), no podstatný rozdiel sa ukazuje $\mathrm{v}$ tom, čo odlišuje moderné chápanie dedukcie (teda deduktívnych argumentov) od moderných koncepcií indukcie a abdukcie. Hoci Aliseda $(2006$; 2017) si všíma existujúce rozdiely v modernom chápaní indukcie a abdukcie, oba typy argumentov sú - na rozdiel od dedukcie - nemonotónne. Deduktívne (logicky platné) argumenty sú totiž založené na relácii logického vyplývania (v určitom jazyku), ktorá je monotónna, čo značí, že ak z množiny výrokov $\Theta$ vyplýva výrok $\phi$, tak aj z rozšírenia množiny výrokov $\Theta$ o lubovol’ný výrok $\alpha$ vyplýva výrok $\phi$. Teda ak $\Theta \vDash \phi$, tak $\Theta \cup\{\alpha\} \vDash \phi$. Na druhej strane relácia medzi množinou premís a záverom induktívnych aj abduktívnych argumentov je nemonotónna - to znamená, že ak množina premís $\Theta$ induktívne alebo abduktívne podporuje záver $\phi$, pridanie novej informácie $\alpha$ môže pôvodnú reláciu podpory narušit' či anulovat'. O indukcii i abdukcii teda platí, že ide o nemonotónne argumenty. Navyše oba druhy argumentov rozširujú naše poznanie - ich záver totiž obsahuje informáciu, ktorá nie je obsiahnutá v premisách (Douven 2017; Schurz 2008). V čom sa však líšia induktívne argumenty (rôznej formy) od abdukcie?

Základný rozdiel tkvie $\mathrm{v}$ tom, že vzt’ah medzi premisami a závermi indukcie je modelovaný (len) na základe pojmu (respektíve teórie) pravdepodobnosti, kým vzt’ah medzi premisami a závermi abdukcie je daný explanačným vzt’ahom: záver abduktívneho argumentu sa prijíma (dočasne) ako (najlepšie / najlepšie dostupné) vysvetlenie evidencie uvedenej $\mathrm{v}$ jednej z premís argumentu - a teda existuje explanačné spojenie medzi hypotézou a evidenciou, ktoré v argumente vystupujú (pozri Douven 2017). Schurz $(2008,202)$ formuluje rozdiel medzi indukciou a abdukciou v ich zacielení. Kým indukcia smeruje k odvodeniu informácie, ktorá sa týka budúceho sledu udalostí, abdukcia je zameraná na odvodenie informácie o nepozorovaných príčinách či explanačných dôvodoch udalostí, ktoré sme pozorovali. 
Modernú logickú podobu abdukcie, s ktorou sa môžeme stretnút' u viacerých autorov, zachytáva nasledujúca schéma (pozri Lycan 1988; Josephson \& Josephson 1996; Niiniluoto 1999; 2018):

\section{(MA)}

E (je stav vecí alebo opis dát)

Hypotéza $\mathrm{H}$ je potenciálnym vysvetlením $\mathrm{E}$.

Žiadna (dostupná) alternatívna hypotéza $\mathrm{H}^{*}$ nevysvetl'uje $\mathrm{E}$ tak dobre ako $\mathrm{H}$.

H je (pravdepodobne) pravdivá / potvrdená / akceptovaná.

Schéma (MA) sa v niekol'kých ohl'adoch líši od schémy (PA): 1) Predmetný stav vecí E, ktorého vysvetlenie sa požaduje, nie je v (MA) kvalifikovaný ako prekvapivý. Prekvapivost' faktu E, ktorá vystupuje v schéme (PA), je subjektívnou črtou (X môže byt' prekvapivé pre jednu osobu, no samozrejmé pre inú osobu), od ktorej schéma (MA) abstrahuje. E tak v (MA) predstavuje neutrálnu (výrokovú) premennú, za ktorú možno dosadit' (v danom kontexte) opis takého stavu vecí, ktorého vysvetlenie sa požaduje. ${ }^{5}$ 2) Kým v schéme (PA) vystupovala (ako potenciálne vysvetlenie) jediná hypotéza $\mathrm{H}$, schéma (MA) predpokladá existenciu viacerých alternatívnych hypotéz. 3) Premisy (MA) zahŕňajú informáciu o explanačnej preferencii jednej spomedzi uvažovaných hypotéz, ktorá prirodzene chýba v (PA). 4) Zatial' čo Peirce sa v schéme (PA) prikláňa $\mathrm{k}$ takej interpretácii záveru, podl’a ktorej je explanačná súvislost' hypotézy s prekvapivým faktom dôvodom na jej prvotnú prijatel'nost', pričom však danú hypotézu treba d'alej (neabduktívne) testovat' (pozri Psillos 2011), schéma (MA) pripúšt’a aj silnejšiu - konfirmačnú interpretáciu záveru.

Treba povedat', že v moderných diskusiách o abduktívnom usudzovaní a argumentoch sa vyskytujú viaceré varianty schémy (MA), ktoré sa od seba v určitých aspektoch líšia. Napríklad kým niektorí autori pracujú s požiadavkou, aby množina zvažovaných hypotéz, ktoré predstavujú potenciálne vysvetlenie E, bola množinou navzájom sa vylučujúcich hypotéz, iní túto požiadavku doplñajú aj o podmienku, že má íst' o množinu navzájom sa vylučujúcich a spolu vyčerpávajúcich hypotéz, kým d’alší autori nespresňujú, o akú množinu hypotéz má íst'. ${ }^{6}$

\footnotetext{
${ }^{5}$ Dá sa uvažovat' o tom, že stav vecí E je len možný, teda že ide o predikciu určitého očakávaného stavu vecí. Pozri Gahér (2017).

${ }^{6}$ Viac o niektorých moderných podobách abduktívnej inference pozri v Douven (2017), Niiniluoto (2018) či Schurz (2008).
} 


\section{Funkcie abdukcie}

Pôvodná Peircova koncepcia abduckie i jej moderné podoby sa zhodujú v tom, že ide o druh explanačnej inferencie (úsudku). Vynára sa otázka, pri akých typoch okolností možno použit' abdukciu a aké funkcie môže mat' jej využitie v usudzovaní?

Viacerí autori rozlišujú dve základné funkcie abdukcie, ktoré sú naviazané na dve tradičné kategórie kontextov vo filozofii vedy (pozri Douven 2017; Magnani 2001; Niiniluoto 1999; 2018; Schurz 2008): a) Abdukciu je možné použit' na návrh, generovanie či formuláciu explanačnej hypotézy. V takom prípade hovoríme, že abdukcia sa dá použit' v kontexte objavu. Avšak b) abdukciu môžeme použit' aj na potvrdenie, zdôvodnenie či akceptáciu explanačnej hypotézy, a teda abdukcia je v takom prípade spojená s kontextom zdôvodnenia. Navyše moderná podoba abdukcie v kontexte zdôvodnenia je známa aj ako odvodenie najlepšieho vysvetlenia (angl. inference to the best explanation) a popri priekopníckej práci Gilberta Harmana (Harman 1965) sa tejto jej podobe systematicky venoval Peter Lipton (Lipton 2004).

Obe funkcie abdukcie - kreatívna i konfirmačná - sú však spojené s viacerými odlišnými aspektmi abduktívnych argumentov, ktoré sa prejavujú ako na úrovni ich logickej formy, tak aj na úrovni metodologických kritérií, ktorými sa dané argumenty (či ich jednotlivé zložky) posudzujú. Hoci na tomto mieste nie je priestor na ich detailný rozbor, predsa len poukážem na niektoré základné rozdiely medzi abdukciou použitou v kontexte objavu a abdukciou použitou v kontexte zdôvodnenia.

Abdukcia použitá v kontexte objavu má svojou formou blízko k pôvodnej Peircovej schéme (PA). Hoci autori, ktorí sa vyjadrujú ku kreatívnej funkcii, rozlišujú viaceré formy abdukcie, základnú formu abdukcie $v$ tomto kontexte predstavuje schéma:

(AO1)

E je pravda.

Ak by $\mathrm{H}$ bola pravda, $\mathrm{E}$ by bola pravda.

H je (dočasne) prijatel'ný návrh hypotézy.

Záver argumentu formy (AO1) vyjadruje informáciu, že o hypotéze H má zmysel d'alej uvažovat', a teda tento druh argumentu môže generovat' explanačné hypotézy, ktoré si vyžadujú d’alšie (samostatné) testovanie. Peircova schéma (PA) sa od schémy (AO1) líši len hodnotením prvej premisy a hodnotením hypotézy zo záveru, no obe schémy v princípe zachytávajú výsledok použitia abduktívneho usudzovania, ktorým je nová hypotéza. 
Niektorí autori ako Niiniluoto $(2018,76$ - 79) však upozorňujú, že schéma (AO1) nie je vhodnou reprezentáciou kreatívneho použitia abdukcie. Kreatívna funkcia abdukcie sa totiž spája s presvedčením, že záver abdukcie obsahuje (novú) hypotézu, o ktorej sa doteraz neuvažovalo, a teda že záver je tým miestom, ktoré má generovat' hypotézu. Avšak v schéme (AO1) vidíme, že hypotéza zo záveru je zmienená aj v druhej premise. Niiniluoto preto spája s kontextom objavu skôr argument, ktorý má formu (pozri Niiniluoto 2018, 78):

\section{(AO2)}

E je pravda.

Je dôvod mysliet' si, že nejaká hypotéza druhu D vysvetl'uje E.

Je dôvod mysliet' si, že nejaká hypotéza druhu D je prijatel'ná / pravdivá.

Úsudok formy (AO2) sa od schémy (AO1) líši najmä v tom, že nezmieňuje konkrétnu hypotézu $\mathrm{H}$ (ani v premisách, ani v závere), ktorá by bola (ideálnym) potenciálnym vysvetlením E, ale hovorí o určitých aspektoch, ktoré by mala mat' hl'adaná explanačná hypotéza.

Niiniluotov návrh schémy (AO2) však nie je uspokojivým riešením problému abdukcie ako inferencie, ktorá generuje nové explanačné hypotézy. Totiž pôvodný problém - že záver abdukcie v schéme (AO1) len opakuje hypotézu, ktorá figuruje medzi premisami - sa tu nahrádza iným problémom: v schéme (AO2) sa zbavujeme zmienky o konkrétnej hypotéze nielen v premisách, ale aj v závere argumentu.

Domnievam sa, že spochybňovanie schémy (AO1) ako schémy zachytávajúcej abdukciu v kontexte objavu vzniká v dôsledku dvoch vecí: 1) Nerozlišuje sa tu dostatočne medzi abduktívnym usudzovaním ako procesom, ktorý prebieha v konkrétnom čase a priestore, a abduktívnym argumentom, ktorý je vyjadrením (niektorých aspektov) výsledku takéhoto procesu. 2) Proces generovania hypotéz sa (bez adekvátneho zdôvodnenia) spája s požiadavkou, že objavená hypotéza $\mathrm{H}$ by sa mala (prvýkrát) vyskytnút' len v závere úsudku. Možno však v tejto súvislosti poukázat' na fakt, že schéma (AO1) nezachytáva proces usudzovania, ale jeho (atemporálne reprezentovaný) výsledok. A viaceré vlastnosti, ktoré procesu usudzovania náležia (napríklad objavenie hypotézy $\mathrm{H} v$ čase $t$, uvedomenie si jej explanačného spojenia s $E$ v čase $t+m$, prijatie $H$ ako prijatel'ného návrhu v čase $t+n$, atd'.) nie sú vlastnost’ami, ktoré zachytáva výsledný (rekonštruovaný) produkt takéhoto procesu. Navyše, nie je zrejmé, prečo by sme mali o abdukcii uvažovat' ako o prostriedku generovania hypotéz len za predpokladu, že nová hypotéza sa objavuje iba v závere argumentu. Proces generovania hypotézy predsa nemusí byt' spojený len so záverom abdukcie, ale aj s jej premisou (či premisami). 
Druhou základnou funkciou abdukcie (odvodenia najlepšieho vysvetlenia) je jej konfirmačné použitie $\mathrm{v}$ kontexte zdôvodnenia. Explanačné usudzovanie totiž môže viest' k prijatiu jednej spomedzi viacerých uvažovaných hypotéz. Proces selekcie výslednej hypotézy je pritom ovplyvnený viacerými faktormi, ktoré sa môžu „podpísat"“ pod výber jednej z uvažovaných hypotéz ako najlepšieho vysvetlenia. Abdukcia v kontexte zdôvodnenia má pritom zvyčajne podobu zodpovedajúcu argumentu formy (MA) či jej modifikácii:

\section{(MA*)}

E je pravda.

$\mathrm{H}_{1}, \ldots, \mathrm{H}_{\mathrm{n}}$ sú potenciálne vysvetlenia $\mathrm{E}$.

$\mathrm{H}_{\mathrm{i}}$ vysvetluje E lepšie ako ostatné hypotézy.

$\mathrm{H}_{\mathrm{i}}$ je dostatočne dobré vysvetlenie $\mathrm{E}$.

$\mathrm{H}_{\mathrm{i}}$ je (pravdepodobne) pravda.

Schéma (MA*) reflektuje námietku, ktorú voči abdukcii vo forme (MA) vzniesol Bas van Fraassen (pozri van Fraassen 1989, 143 a d'alej). Van Fraassen totiž tvrdil, že množina hypotéz $\mathrm{H}_{1}, \ldots, \mathrm{H}_{\mathrm{n}}$ síce môže obsahovat' hypotézu $\mathrm{H}_{\mathrm{i}}$, ktorá je lepším vysvetlením $\mathrm{E}$ ako zvyšné hypotézy, no ak daná množina neobsahuje všetky navzájom sa vylučujúce a spolu vyčerpávajúce hypotézy, môže sa stat', že v nej chýba práve tá správna (pravdivá) hypotéza, ktorá je skutočným vysvetlením E. V takom prípade však fakt, že $\mathrm{H}_{\mathrm{i}}$ vysvetl'uje $\mathrm{E}$ lepšie ako ostatné hypotézy, je zlučitel'ný s faktom, že $H_{i}$ je nesprávne vysvetlenie. Preto Lipton (2004) navrhol nahradit' schému (MA) schémou (MA*), ktorá má dodatočnú premisu vyjadrujúcu predpoklad, že hypotéza $\mathrm{H}_{\mathrm{i}}$, ktorú spomedzi hypotéz $\mathrm{H}_{1}, \ldots, \mathrm{H}_{\mathrm{n}}$ vyberáme, je sama osebe dostatočne dobrým vysvetlením E. Hoci Lipton nešpecifikoval, čo konkrétne znamená, že hypotéza H je dostatočne dobrým vysvetlením E, môžeme predpokladat', že určitý model explanácie môže pre určitý stav vecí E ponúknut' kritériá adekvátneho, a teda dostatočne dobrého vysvetlenia. ${ }^{7}$

Okrem tradičných funkcií abdukcie - kreatívnej a konfirmačnej, ktorým zodpovedajú aj tradičné kontexty objavu a zdôvodnenia, možno rozlíšit’ aj osobitý modus operandi vysvetlenia. Abdukciu totiž možno použit' aj v kontexte aplikácie teórie, kde ciel’om použitia nie je ani formulácia novej hypotézy (kontext objavu), ani potvrdenie a selekcia jednej spomedzi viacerých hypotéz (kontext zdôvodnenia), ale výber takých antecedentných podmienok jednej spomedzi etablovaných (potvrdených a akceptovaných)

\footnotetext{
${ }^{7}$ Klasickou neprekonanou prácou, ktorá mapuje hlavné modely vedeckého vysvetlenia $\mathrm{v}$ štyroch dekádach od publikovania programovej práce Carla G. Hempela a Paula Oppenheima (Hempel, Oppenheim 1948), je Salmon (1990). Aktuálny prehl’ad hlavných modelov explanácie pozri v Bonnay (2018).
} 
hypotéz, ktoré vzhl'adom na dané okolnosti a východiskové poznanie B predstavujú najlepšie vysvetlenie E. ${ }^{8}$ Typickým prípadom tohto kontextu abduktívneho usudzovania je diagnostika ochorenia určitej osoby či rekonštrukcia konkrétnych príčin určitého javu (napríklad leteckej nehody). V tomto prípade totiž platí, že premisy abduktívneho argumentu obsahujú všetky relevantné hypotézy, ktoré boli doteraz potvrdené a sú akceptované, pričom úlohou je vybrat' tie konkretizované antecedentné podmienky jednej z hypotéz, ktoré sa vzhl'adom na určitú bázu poznatkov ukazujú ako najpravdepodobnejšie. Príklad použitia abdukcie v kontexte aplikácie teórie zachytáva nasledujúci argument:

(AAT)

Osoba $a$ má zvýšenú teplotu a červený výsyp. (E)

Každý, kto sa nakazí Morbilli vírusom (osýpky), má zvýšenú teplotu a červený výsyp. $\left(\mathrm{H}_{1}\right)$

Každý, kto sa nakazí Rubivírusom, má zvýšenú teplotu a červený výsyp. $\left(\mathrm{H}_{2}\right)$ Osoba $a$ sa v minulosti nakazila Morbilli vírusom. (B)

Ktokol'vek sa v minulosti nakazil Morbilli vírusom, je voči opakovanej nákaze imúnny. (B)

Osoba $a$ sa nakazila (pravdepodobne) Rubivírusom. $\left(\mathrm{AH}_{2}\right)$

Všimnime si, že záver $\left(\mathrm{AH}_{2}\right)$ argumentu (AAT) neobsahuje ani hypotézu $\mathrm{H}_{1}$, ani hypotézu $\mathrm{H}_{2}$. Obsahuje však opis antecedentných podmienok hypotézy $\mathrm{H}_{2}$, ktoré sa týkajú konkrétnej osoby. Ciel'om tohto argumentu nie je generovat' explanačné hypotézy - tie už sú predsa sformulované. A podobne tak nie je ciel'om ani potvrdenie hypotéz $\mathrm{H}_{1}$ alebo $\mathrm{H}_{2}$. Obe hypotézy sa v infektológii a epidemiológii pokladajú za potvrdené a obe možno vo vhodnom kontexte diagnostiky použit' na určenie konkrétnej diagnózy. Argument (AAT) zachytáva aplikáciu konkrétnej teórie (hypotézy $\mathrm{H}_{2}$ ) na vysvetlenie javu opísaného výrokom E, čo možno popri kreatívnej i konfirmačnej funkcii vymedzit' ako osobitnú funkciu.

\section{Abdukcia vo vede a filozofii}

Téza, že abdukcia patrí k základným inferenčným nástrojom vedeckého skúmania, je vo všeobecnosti rozšírená (pozri napríklad Aliseda 2006; Douven 2017; Lipton 2004; Schurz 2008). Sú však filozofi, ktorí obhajujú používanie abdukcie aj vo filozofii. Napríklad Timothy Williamson v jednej z nedávnych štúdií uvádza: „Mám zato, že filozofia by mala používat' široko abduktívnu metodológiu“ (Williamson

${ }^{8}$ Vo svojej dávnejšej práci (Bielik 2012) som predpokladal, že abdukciu možno použit' ako explanačný úsudok sui generis, no robil som to bez odlíšenia troch uvedených kontextov abdukcie. 
2016, 268). Podobne Paul Thagard vo svojej známej štúdii o abdukcii v závere konštatuje: „Posledné pozitívum vyššie uvedenej koncepcie, ktoré na tomto mieste uvádzam, je fakt, že (abdukcia - pozn. autora) umožňuje zjednotenie vedeckej a filozofickej metódy, pretože odvodenie najlepšieho vysvetlenia má mnohé aplikácie vo filozofii, predovšetkým v metafyzike“" (Thagard 1978, 92).

Prečo však používat' abdukciu vo filozofiii? Williamson (2016) si všíma najmä dva dôvody, pre ktoré je abdukcia vo filozofii potrebná: 1) Abdukciu možno využit' na zdôvodnenie logických i mimologických axióm a princípov, ktoré využívame pri dedukcii; 2) Dedukcia slúži na odvodenie dôsledkov z explanačných hypotéz, ktoré sme získali abdukciou. Thagard (1978) zase vidí prospešnost' abdukcie (ako odvodenia najlepšieho vysvetlenia) v tom, že abduktívna inferencia porovnáva nielen hypotézu (teóriu) s evidenciou, ale aj konkurenčné hypotézy medzi sebou, a to na základe ich metodologicky relevantných vlastností. Abduktívne usudzovanie je tak usudzovaním v širších súvislostiach, čo sa môže (aspoň v niektorých prípadoch) pretavit' do robustnejšej podpory určitej filozofickej (hypo)tézy.

Ak teda predpokladáme, že abdukcia má svoje miesto vo vede i vo filozofii, v d'alšom kroku sa možno pýtat', či medzi abdukciou a jej používaním vo vede a vo filozofii existujú nejaké kognitívne relevantné rozdiely. V zvyšnej časti tejto štúdie ponúkam dôvody v prospech tézy, že takéto rozdiely existujú. Charakteristiky, v ktorých sa abdukcia vo vede líši od abdukcie vo filozofii, možno reprezentovat' nasledujúcimi otázkami:

a) Akú povahu má $\mathrm{H}$ a akú E?

b) Čo znamená povedat', že H vysvetluje E?

c) V ktorých kontextoch sa abdukcia využíva?

d) Aké kritériá selekcie rozhodujú o výbere najlepšieho vysvetlenia?

Všetky štyri otázky tu treba chápat’ ako relativizované k spomínaným dvom oblastiam - k oblasti (empirickej) vedy a filozofie. Na viaceré rozdiely teraz poukážem.

Ad a)

Otázku „Akú povahu má H a akú E?“, kde H je hypotéza a E je evidenčný výrok, tu kladiem ako otázku o logicko-sémantickom alebo metodologickom rozdiele uvedených druhov výrokov vo vede a filozofii. Nie je zrejme žiadnym prekvapením, ked' tvrdím, že vedecké hypotézy sú z logicko-sémantického hladiska logicky kontingentné výroky, ktoré sú bud' pravdivé, alebo nepravdivé. Toto tvrdenie je v súlade s možnost'ou, že niektoré logicky kontingentné výroky reprezentujú (predpokladané) zákony prírody, pričom s týmito výrokmi spájame predpoklad mimologickej nutnosti (ide o tzv. nomologickú nutnost'). Navyše z metodologického hl'adiska 
kladieme na vedecké hypotézy aj požiadavku empirickej testovatel’nosti. Hypotéza je pritom testovatel'ná, ak sú myslitel'né také pozorovatel'né okolnosti, ktoré by ju spochybnili či oslabili.

Ak sa na druhej strane pozrieme na filozofické tézy ako na špecifický typ hypotéz, nemôžeme prehliadnut' fakt, že väčšina z nich má modálny profil typu „Je možné, že p“, „Je nutné, že p“ alebo „Je nemožné, že p“, kde $p$ je určitý výrok (propozícia), pričom modality možnosti, nutnosti či nemožnosti sú zvyčajne bud’ logického alebo konceptuálneho (sémantického) druhu. Ako príklad možno uviest' nasledujúce hypotézy: „Je možné, že poznanie nie je (to isté ako) pravdivé zdôvodnené presvedčenie“ či „,(Je nutné, že:) Významom X je Y“, prípadne „Nie je možné, že rigidný designátor referuje $\mathrm{v}$ odlišných možných svetoch na odlišné indivídua“ a pod. Fakt, že vel'ká čast' filozofických hypotéz obsahuje uvedené modality, nie je $\mathrm{v}$ rozpore s tým, že existuje čast' filozofických hypotéz, ktoré majú charakter kontingentne pravdivých či nepravdivých výrokov. Medzi ne možno zaradit' napríklad tézu (vedeckého realizmu), že naše súčasné vedecké teórie sú (aproximatívne) pravdivé, alebo hypotézu, že vonkajší svet existuje. Tieto hypotézy sú bud' pravdivé, alebo nepravdivé, no nepokladáme ich za nutne pravdivé či nutne nepravdivé.

Vrát'me sa však k filozofickým hypotézam s modálnym profilom (nutnosti, možnosti a nemožnosti). Hoci platí, že niektoré empirické okolnosti môžu predstavovat' negatívnu evidenciu voči nutnosti či nemožnosti a niektoré iné okolnosti môžu predstavovat' pozitívnu evidenciu pre možnost', vo všeobecnosti nie je pravdou, že by sa všetky modálne hypotézy dali testovat' empirickou evidenciou. Napríklad na spochybnenie filozofickej tézy formy ,je nemožné, že p“ stačí uviest' myslitel'ný prípad formy ,je možné, že p“. Možný stav vecí, opísaný výrokom $p$ však nemusí byt' nikdy pozorovaný, aby predstavoval negatívnu evidenciu výroku formy „je nemožné, že p“. Jednoducho stačí poukázat' na taký možný prípad, z ktorého vyplýva, že je možné, že p.

Podobný rozdiel, aký možno postrehnút' medzi vedeckými a filozofickými hypotézami, je aj medzi evidenčnými výrokmi. Kým vo vede evidenčné výroky reprezentujú intersubjektívne prístupné a v princípe pozorovatel'né okolnosti, výroky, ktoré plnia funkciu evidencie vo vzt'ahu k filozofickým hypotézam, môžu mat' modálny profil. Navyše niektorí filozofi prihliadajú na vlastné intuície či iné introspektívne dáta ako na relevantnú evidenciu vo vzt’ahu k modálnym výrokom. A teda kritériá kladené na evidenciu v empirickej vede nie sú totožné s kritériami, ktoré kladieme na filozofickú evidenciu.

Môžeme teda konštatovat', že logicko-sémantická povaha hypotéz a evidencie, ako aj metodologické kritériá, ktoré na ne kladieme, sa v týchto oblastiach líšia. 
(Tým nie je vylúčená možnost', že niektoré fillozofické prístupy - napríklad naturalizovaná epistemológia či experimentálna filozofia - sú v tomto ohl'ade výnimkou.)

Ad b)

Ďalší rozdiel medzi abdukciou vo vede a abdukciou vo filozofii sa ukazuje na úrovni modelu či modelov vysvetlenia. Hoci vo filozofii vedy neexistuje konsenzus na tom, ktorý model alebo modely vedeckého vysvetlenia reprezentujú spol'ahlivé a prijatel'né kritériá explanácie, všetky doteraz navrhnuté koncepcie predstavujú konkrétnu odpoved' na otázku „Čo znamená povedat', že $\mathrm{H}$ vysvetl'uje E?“. Vysvetlením vo vede sa (v niektorých prípadoch) môže rozumiet' subsumpcia evidencie E pod hypotézu H, prípadne poskytnutie kauzálne relevantných informácií, opis mechanizmu, určitý druh pravdepodobnostnej závislosti alebo určitá schéma zjednotenia empirických stavov vecí a regularít (pozri Salmon 1990; Bonnay 2018). Každý z modelov explanácie predstavuje osobitnú odpoved' na otázku, čo znamená vysvetlit' určitý jav. Je to pochopitel'né, pretože vedecké hypotézy môžu vyjadrovat' určitú príčinnú alebo funkčnú závislost', môžu byt' univerzálne i pravdepodobnostné a môžu referovat' na určitý mechanizmus či spoločné, empiricky testovatel’né princípy, ktoré sú v pozadí empirických javov.

Na druhej strane sa zdá, že filozofi, ktorí uvažujú o využití abdukcie vo filozofii, nepracujú s nejakou konkrétnou koncepciou vysvetlenia, ktorá má svoje využitie v empirickej vede. Skôr možno vybadat', že niektorí používajú výroky „H vysvetl’uje E“ a „z H

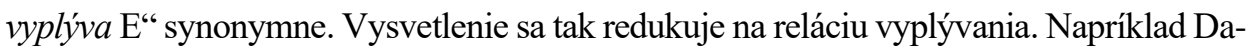
vid M. Armstrong pri obhajobe svojej koncepcie zákonov prírody ako relácie $\mathrm{N}$ kontingentnej nevyhnutnosti medzi všeobecninami $F$ a G hovorí, že regularity formy ,„š̌etky $F$ sú $\mathrm{G}$ “ sú vysvetlené postulátom „N(F, G)“ - ktorý vyjadruje reláciu medzi všeobecninami - pretože z „N(F, G)“ vyplýva „,v̌̌tky F sú G“ (pozri Armstrong 1983, 96, 97 a 104). ${ }^{9} \mathrm{Na}$ obhajobu svojej koncepcie Armstrong pritom využíva práve abduktívny argument. S podobným chápaním vysvetlenia v prípade použitia abdukcie vo filozofii sa môžeme stretnút' aj u d'alších autorov (pozri napríklad Psillos 1999, kap. 4). Povedat' teda, že H vysvetl'uje $\mathrm{E}$, je vo filozofických textoch o abdukcii vel'mi blízke, alebo priam totožné s tým, ked’ sa povie, že z H vyplýva E, prípadne, že H robí E vysoko pravdepodobným.

Ad c)

Ak sa pozrieme na bohatú literatúru, ktorá mapuje využívanie abdukcie vo vede, nie je pochýb o tom, že abdukcia môže viest' $\mathrm{k}$ návrhu a formulácii nových hypotéz

\footnotetext{
${ }^{9}$ Reláciu N medzi určitými univerzáliami F a G tu možno chápat' analogicky k relácii nomologickej nutnosti. Nejde o prípad logickej nutnosti - ktorú možno definovat' prostredníctvom množiny všetkých možných svetov, v ktorých je určitá propozícia pravdivá, ale o prípad slabšej nutnosti, kde uvažujeme len o podmnožine možných svetov, v ktorých je daná propozícia nomologicky pravdivá, no zároveň ide o (vlastnú) nadmnožinu tých možných svetov, ktoré tvoria aktuálny svet.
} 
(kontext objavu), rovnako ako môže byt' zapojená do procesu potvrdenia či zdôvodnenia hypotéz (kontext zdôvodnenia). Navyše existujú príklady abduktívnych úsudkov podobné argumentu (AAT), v ktorých abdukciu využívame ako osobitý spôsob vysvetlenia konkrétneho javu (kontext aplikácie). $\mathrm{V}$ tomto zmysle abduktívny záver referuje na (pravdepodobnú) inštanciu príčiny, ktorá viedla $\mathrm{k}$ stavu vecí $\mathrm{E}$.

Podobne aj vo filozofii použitie abdukcie môže viest' k návrhu nových hypotéz. Vymýšl'anie hypotetických scenárov, ktoré by „vysvetl'ovali“ určité filozofické presvedčenia, je neraz výsledkom abduktívneho usudzovania. Napríklad Descartovu hypotézu o klamúcom démonovi možno tiež rekonštruovat' ako výsledok abduktívneho usudzovania: ${ }^{10}$ Zdá sa mi, že pozorujem oblohu, farby, zem a pod.; keby ma klamal zlomysel'ný duch, zdalo by sa mi tiež, že pozorujem oblohu, farby, zem a pod., teda zvážim skeptickú hypotézu, že existuje démon, ktorý ma klame (pozri Descartes 1997, 26). V tomto i d’alších prípadoch filozofického uvažovania abdukcia prispieva ku generovaniu hypotéz.

Podobne možno vybadat', že filozofické argumenty, ktorými sa zdôvodňuje prijatel'nost' takých hypotéz, akými sú téza vedeckého realizmu či hypotéza o existencii vonkajšieho sveta, plnia konfirmačnú funkciu. Abdukcia vo filozofii má teda svoje miesto v kontexte objavu i v kontexte zdôvodnenia.

Ako je to však s kontextom aplikácie teórie? Čo by znamenalo povedat', že abdukciu vo filozofii možno použit' aj na účely explanačnej aplikácie nejakej teórie? Po prvé by to znamenalo, že pracujeme s množinou alternatívnych, no testovatel'ných a dobre potvrdených filozofických hypotéz. $Z$ toho, čo sme uviedli v bode a), však možno usúdit', že filozofické hypotézy nie sú vo všeobecnosti empiricky testovatel'né. Po druhé, ciel’om návrhu a použitia fillozofických hypotéz nie je vysvetlenie konkrétnych javov či udalostí (typu „Prečo má XY symptóm Z?“ alebo „Prečo má konkrétny objekt $a$ vlastnost' $F$ ?"). Filozofické otázky a odpovede programovo smerujú $\mathrm{k}$ analýze a zdôvodneniu všeobecných čŕt reality, nášho poznania či kritérií hodnotenia nášho konania, a nie k partikulárnym javom.

Ak sú predpoklady našej úvahy správne, tak rozdiel medzi abdukciou vo vede a vo filozofii sa ukazuje aj na úrovni kontextu použitia: abdukcia vo vede má svoje miesto vo všetkých troch kontextoch, zatial' čo filozofický výskyt abduktívneho usudzovania sa viaže len na prvé dva kontexty.

\footnotetext{
${ }^{10}$ Za upozornenie na možnost' abduktívnej rekonštrukcie Descartovej hypotézy o klamúcom démonovi vd’ačím Marekovi Pichovi. Podobne tak aj za upozornenie na úzke prepojenie abduktívneho usudzovania s myšlienkovými experimentmi. Viac o klasických filozofických myšlienkových experimentoch pozri Picha, Pichová (2013).
} 
Ad d)

Posledný rozdiel, ktorý stojí za povšimnutie, sa týka kritérií selekcie jednej spomedzi viacerých hypotéz. Tento problém sa ukazuje najmä v prípade abdukcie použitej na zdôvodnenie či potvrdenie určitej hypotézy (ide teda o kontext zdôvodnenia).

Vo filozofickej literatúre sa objavujú viaceré práce o žiaducich metodologických vlastnostiach a kritériách, ktoré môžu pomôct' pri výbere jednej z viacerých hypotéz. Napríklad Paul Thagard (1978) hovorí o jednoduchosti, zhode s ostatnými poznatkami (angl. consilience) a analógii. Ďalší, ako napríklad Lycan $(1988,130)$, pridávajú aj iné podmienky, akými sú explanačný dosah („Ceteris paribus, preferuj teórie, ktoré vysvetl'ujú viac druhov javov ako konkurenčné teórie!"), miera testovatel'nosti, miera otvorených problémov a pod. Tieto, no prípadne aj d'alšie kritériá a ich (odlišná) váha môžu viest' $\mathrm{k}$ výberu práve jednej hypotézy ako toho najlepsieho vysvetlenia $\mathrm{E}$.

Sú však tieto kritériá rovnako uplatnitel'né na vedecké a filozofické hypotézy? To zrejme nie, pretože - ako sme videli - filozofické hypotézy sa od tých vedeckých líšia aj čo do svojho logicko-sémantického profilu, aj metodologickými štandardmi, podl'a ktorých ich posudzujeme. Ak totiž vo filozofii pracujeme s apriórnou a analytickou hypotézou (napríklad formy ,je možné, že p“), zrejme na ňu nemožno uplatnit' kritérium miery testovatel'nosti, ktoré sa týka empirických vedeckých hypotéz. Ak filozofické hypotézy s modálnym profilom považujeme za testovatel'né, tak zrejme $\mathrm{v}$ inom zmysle slova a inými prostriedkami, ako je to štandardom v prípade vedeckých hypotéz. Podobný problém vzniká aj pri niektorých d’alších kritériách. Keby sme úvahu o explanačnom dosahu doviedli do absurdnosti, mohli by sme tvrdit', že explanačný dosah vo filozofii možno - podobne ako v prípade koncepcie vysvetlenia v časti b) - stotožnit's deduktívnymi dôsledkami danej hypotézy. Inak povedané, čím viac logických dôsledkov (v danom jazyku) môžeme z hypotézy odvodit', tým má väčší explanačný dosah. To by však znamenalo, že logické kontradikcie majú väčší explanačný dosah ako tautológie, pretože z kontradikcií vyplýva čokol'vek. Preto ak má kritérium explanačného dosahu plnit' pri hodnotení filozofických hypotéz konštruktívnu funkciu, nemožno ho stotožnit' s množinou deduktívnych dôsledkov danej hypotézy. V prípade vedeckých hypotéz je však kritérium explanačného dosahu prirodzene aplikovatel'né. Ak porovnávame dve empirické teórie, $\mathrm{T}_{1}$ a $\mathrm{T}_{2}, \mathrm{z}$ ktorých jedna môže vysvetlit' viac druhov javov ako druhá, tak ceteris paribus, je vhodné preferovat' $\mathrm{T}_{1}$ pred $\mathrm{T}_{2}$.

To však neznamená, že niektoré vlastnosti hypotéz, akou je napríklad jednoduchost', nezohrávajú podobnú rolu pri výbere vedeckých i filozofických hypotéz. To, na čo upozorňujem, je fakt, že odlišná povaha vedeckých a filozofických hypotéz sa odráža aj v odlišných kritériách, ktorými pomeriavame súperiace hypotézy 
v jednej a druhej oblasti. A preto ani to, čo sa rozumie najlepším vysvetlením v prípade vedeckých hypotéz, nebude totožné s tým, čo sa najlepším vysvetlením rozumie v prípade filozofických hypotéz.

\section{Na záver}

V tejto štúdii som predstavil hlavné logické i metodologické charakteristiky abduktívnych argumentov a odlišsil som tri základné funkcie, ktoré sa viažu na tri druhy kontextov použitia abdukcie. Osobitne som sa venoval otázke niektorých kognitívne relevantných rozdielov medzi používaním abdukcie vo vede a vo filozofii. Išlo predovšetkým o rozdiel v povahe vedeckých a filozofických hypotéz a evidenčných výrokov, ktorý sa prejavuje $\mathrm{v}$ ich odlišnom logicko-sémantickom profile i metodologických kritériách, ktoré na ne kladieme. Ukázalo sa tiež, že kým vedecké vysvetlenia sa opierajú o príčinnú alebo pravdepodobnostnú závislost', subsumpciu pod vedecké zákony, určitý mechanizmus či schému zjednotenia, filozofické vysvetlenia sa na tieto faktory neodvolávajú. Pojem vysvetlenia je v prípade abdukcie bud' neanalyzovaný, alebo má blízko k stotožneniu relácie vysvetlenia s reláciou vyplývania. Odlišný charakter vedeckých i filozofických hypotéz sa „podpisuje“ aj pod to, že kým abduktívne argumenty vo vede možno využit' vo všetkých troch kontextoch, filozofické podoby abdukcie sa obmedzujú na kontext objavu a kontext zdôvodnenia. Pritom kritériá, podl’a ktorých posudzujeme výber viacerých uvažovaných hypotéz, sa v oboch oblastiach líšia. Opät' ide o dôsledok odlišného charakteru vedeckých a filozofických hypotéz.

\section{Literatúra}

ALISEDA, A. (2006): Abductive Reasoning. Springer.

ALISEDA, A. (2017): The Logic of Abduction: An Introduction. In: Magnani L. - Bertolotti T. (eds.): Springer Handbook of Model-Based Science. Springer Handbooks. Cham: Springer, 219 - 230. DOI: https://doi.org/10.1007/978-3-319-30526-4_10

ARMSTRONG, M. D. (1983): What Is a Law of Nature? Cambridge: Cambridge University Press. BIELIK, L. (2012): Abduktívny model (vedeckého) vysvetlenia. Organon F 19, Supplementary Issue 1, 5 - 19.

BONNAY, D. (2018): Scientific Explanation. In: Barberousse, A. - Bonnay, D. - Cozic, M. (eds.): The Philosophy of Science. A Companion. New York: Oxford University Press, 3 - 52. DOI: 10.1093/oso/9780190690649.003.0001

CORNMAN, J. W., LEHRER, K., PAPPAS, G. S. (1992): Philosophical Problems and Arguments: An Introduction. 4th ed. Cambridge: Hackett Publishing Company.

DESCARTES, R. (1997): Meditácie o prvej filozofii. Bratislava: Chronos.

DOUVEN, I. (2017): Abduction. In: Zalta, E. N. (ed.): Stanford Encyclopedia of Philosophy. (Summer 2017 Edition). Dostupné na: https://plato.stanford.edu/entries/abduction/

GAHÉR, F. (2017): Deduktívne a abduktívne retrodikcie a predikcie. Filozofia, 72 (8), 616 - 631.

HAIG, B. D. (2014): Investigating the Psychological World. Cambridge - London: A Bradford Book, The MIT Press. 
HAIG, B. D. (2008): Scientific Method, Abduction, and Clinical Reasoning. Journal of Clinical Psychology, 64 (9), 1013 - 1018. DOI: https://doi.org/10.1002/jclp.20505

HARMAN, G. (1965): Inference to the Best Explanation. The Philosophical Review 74, 88 - 95.

HEMPEL, C. G., OPPENHEIM, P. (1948): Studies in the Logic of Explanation. Philosophy of Science 15, $135-175$.

LIPTON, P. (2004): Inference to the Best Explanation. London: Routledge.

LYCAN, W. G. (1988): Judgement and Justification. Cambridge: Cambridge University Press.

JOSEPHSON, J. R. - JOSEPHSON, S. G. (eds.) (1996): Abductive Inference. Computation, Philosophy, Technology. Cambridge: Cambridge University Press.

MAGNANI, L. (2001): Abduction, Reason, and Science: Processes of Discovery and Explanation. New York: Kluwer \& Plenum.

NIINILUOTO, I. (2018): Truth-Seeking by Abduction. Springer. DOI: https://doi.org/10.1007/9783-319-99157-3

NIINILUOTO, I. (1999): Defending Abduction. Philosophy of Science (Proceedings) 66, S436 - S451.

PEIRCE, Ch. S. (1931 - 1958): Collected Papers of Charles Sanders Peirce. Vol. 1 - 8. Cambridge: Belknap Press.

PICHA, M., PICHOVÁ, D. (2013): 100 myšlenkových experimentů ve filozofii. Praha: dybbuk.

PSILLOS, S. (2011): An Explorer upon Untrodden Ground: Peirce on Abduction. In: Gabbay, D. M. - Hartmann, S. - Woods, J. (eds.): Handbook of the History of Logic. Inductive Logic. Vol. 10. Oxford - Amsterdam: North-Holland, 117 - 151.

PSILLOS, S. (1999): Scientific Realism. How Science Tracks Truth. London - New York: Routledge.

SALMON, W. C. (1990): Four Decades of Scientific Explanation. Minneapolis: University of Minnesota Press.

SCHURZ, G. (2008): Patterns of Abduction. Synthese 164, 201 - 234. DOI: https://doi.org/10.1007/ s11229-007-9223-4

THAGARD, P. (1978): The Best Explanation: Criteria for Theory Choice. The Journal of Philosophy, 75 (2), $76-92$.

VAN FRAASSEN, B. (1989): Laws and Symmetry. Oxford: Clarendon Press.

WILLIAMSON, T. (2018): Doing Philosophy. Oxford: Oxford University Press.

WILLIAMSON, T. (2016): Abductive Philosophy. The Philosophical Forum, 263 - 280. DOI: https://doi.org/10.1111/phil.12122

Práca na tomto článku bola podporená projektom č. APVV-17-0057 Analýza, rekonštrukcia a hodnotenie argumentov a projektom VEGA č. 1/0197/20 Postoje v komunikácii a argumentácii: sémantické a pragmatické aspekty.

Lukáš Bielik

Katedra logiky a metodológie vied

Filozofická fakulta UK v Bratislave

Gondova 2

81499 Bratislava

Slovenská republika

e-mail: lukas.bielik@uniba.sk

ORCID ID: https://orcid.org/0000-0002-3918-8392 